\title{
Identification of regional soil quality factors and indicators: a case study on an alluvial plain (central Turkey)
}

\author{
Cevdet Şeker, Hasan Hüseyin Özaytekin, Hamza Negiş, İlknur Gümüş, Mert Dedeoğlu, Emel Atmaca, and \\ Ümmühan Karaca \\ Department of Soil Science and Plant Nutrition, Agriculture Faculty, Selçuk University, 42079 Konya, Turkey \\ Correspondence to: İlknur Gümüş (ersoy@ selcuk.edu.tr)
}

Received: 27 September 2016 - Discussion started: 26 October 2016

Revised: 20 February 2017 - Accepted: 6 March 2017 - Published: 9 May 2017

\begin{abstract}
Sustainable agriculture largely depends on soil quality. The evaluation of agricultural soil quality is essential for economic success and environmental stability in rapidly developing regions. In this context, a wide variety of methods using vastly different indicators are currently used to evaluate soil quality.

This study was conducted in one of the most important irrigated agriculture areas of Konya in central Anatolia, Turkey, to analyze the soil quality indicators of Çumra County in combination with an indicator selection method, with the minimum data set using a total of 38 soil parameters. We therefore determined a minimum data set with principle component analysis to assess soil quality in the study area and soil quality was evaluated on the basis of a scoring function.

From the broad range of soil properties analyzed, the following parameters were chosen: field capacity, bulk density, aggregate stability, and permanent wilting point (from physical soil properties); electrical conductivity, $\mathrm{Mn}$, total nitrogen, available phosphorus, $\mathrm{pH}$, and $\mathrm{NO}_{3}-\mathrm{N}$ (from chemical soil properties); and urease enzyme activity, root health value, organic carbon, respiration, and potentially mineralized nitrogen (from biological properties).

According to the results, the chosen properties were found as the most sensitive indicators of soil quality and they can be used as indicators for evaluating and monitoring soil quality at a regional scale.
\end{abstract}

\section{Introduction}

Soil is an important nonrenewable natural resource on which humanity and most flora and fauna are dependent (Doran and Zeiss, 2000). The ever increasing growth of the human population has brought about a global food safety problem, as obtaining greater efficiency per unit area has become an urgent necessity (Doran, 2002). In developing countries, the intense use of land on the grounds of progress through fast economic development has resulted in serious limitations on the sustainable use of soils and created a major problem in soil quality (SQ) (Arshad and Martin, 2002). Furthermore, the negative effects of land degradation from various causes on agricultural productivity and the indirect effects on environmental and food safety and quality of life have also become global problems. Increasing the amount of agricultural lands may seem to be a solution to fulfill the food demand. Conversely, the amount of agricultural land is already at a maximum level in most countries (Eswaran et al., 2001). Thus, for both the resolution of this problem and the sustainable use of soils, it is much more important to focus on improving the SQ rather than increasing the amount of arable land (Rasheed et al., 1996; Yemefack et al., 2006).

SQ is defined as the capacity of the soil to sustain biological productivity and preserve the environmental quality and health of plants and animals within the boundaries of the ecosystem (Doran and Parkin, 1994). Karlen et al. (1997) defined SQ as the soil's ability to support sustainable plant and animal production, improve human and environmental health, and enhance the quality of water and air as the function of the properties of each soil type, and they regarded it 
as the manifestation of the natural and dynamic properties of soils.

The efficient and sustainable usage of soils, which are among our most important natural resources, can be achieved by defining their properties through proper methods (Doran, 2002), determining the restrictions that affect their productivity and the properties that affect sustainability (Doran and Zeiss, 2000). Assessing and monitoring SQ can provide effective tools for determining the properties of degraded soil (Aronson et al., 1993; Bindraban et al., 2000), revealing sustainable land practices for land managers (Karlen et al., 2011; McGrath and Zhang, 2003) and defining the elements needed for plant nutrition (Yu-Dong et al., 2013). Thus, SQ has received great attention in recent years (Sinha et al., 2014) and the number of studies assessing SQ in different management and product systems has increased worldwide, developing several methods and scoring models for its determination (Andrews et al., 2004; Brandt and Thornes, 1996; Doran et al., 1997, 1996; Doran and Jones, 1996; Doran and Zeiss, 2000; Gugino et al., 2009; Hueso-González et al., 2014; Karlen et al., 1997; Larson and Pierce, 1991; MuñozRojas et al., 2016a).

In the past, SQ was accepted as the natural capacity of soil that provides the main plant nutrients (El-Ramady et al., 2014). However, it is currently regarded as an immaterial property of soils due to its dependency on land usage and soil management practices, ecosystem and environmental interactions, socioeconomic and political priorities, and several other external factors (Doran and Jones, 1996). Thus, it is not possible to use a single soil property to digitize SQ. Conversely, the combined assessment of several parameters formed by the combination of certain soil properties provides important indicators for monitoring and assessing SQ.

In general, SQ parameters are defined as the processes and properties of soil that are sensitive to the changes in soil functions (Aparicio and Costa, 2007; Doran and Jones, 1996). It is very important to establish simple, sensitive, and practical methods for the assessment of SQ and to select indicators accordingly. The quality parameters to be selected must correlate well with the natural processes in the ecosystem (Özulu et al., 2006). They must also be related to the measurable soil functions (natural or human-based); be integrated with the physical, chemical, and biological properties and processes of soil; and be components of the current databases (Aparicio and Costa, 2007; Chen, 1998; Doran and Parkin, 1994; Doran et al., 1996; Dumanski and Pieri, 2000; Herrick and Jones, 2002; Muñoz-Rojas et al., 2016b).

The following properties are reported to be suitable for use as SQ factors and indicators when studies on SQ are carried out: (a) physical properties such as texture, bulk density, water retention, aeration, compression, hydraulic properties, aggregation state, consistence properties, and surface crusting; (b) chemical properties such as $\mathrm{pH}$, salt content, total organic carbon, total nitrogen, organic nitrogen, soluble carbon, mineral nitrogen, total phosphorus, extractable ammonium, ni- trate, phosphor, potassium, calcium, magnesium, microelements, contaminants, and cation change capacity; (c) biological properties such as microbial carbon, microbial nitrogen, soil respiration, biological activity, enzyme activities, root development, germination, and growth; and (d) genetic properties such as soil color, type of structure, the thickness and depth of the impermeable layer that is genetically formed, the thickness of horizon A, and the depth of the clay accumulation horizon (Arshad and Coen, 1992; Blair et al., 1995; Brejda et al., 2000a, b; Burger and Kelting, 1998; Dick et al., 1996; Doran and Parkin, 1994; Fauci and Dick, 1994; Gregorich et al., 1994; Harris et al., 1996; Kay et al., 1996; Larson and Pierce, 1991, 1994; Linden et al., 1994; Powers et al., 1998; Qi et al., 2009; Reganold and Palmer, 1995; Rice et al., 1996; Turco et al., 1992).

To digitize and reveal SQ, it is necessary to determine and score the measurable SQ parameters (Andrews et al., 2002, 2004; Gugino et al., 2009). Several properties affect the SQ in varying degrees (Doran and Parkin, 1994; Harris et al., 1996) and many of the abovementioned physical, chemical, and biological parameters are reported to be suitable for use as indicators (Arshad and Coen, 1992; Brejda et al., 2000a; Doran and Parkin, 1994; Fernandes et al., 2011; Karlen et al., 1997; Larson and Pierce, 1994; Lima et al., 2013). Conversely, the concurrent use of all these properties as quality indicators is both impractical and contrary to the main principles of quality assessment parameters. Doran et al. (1996) advised that the number of indicators used to determine SQ should be as few as possible. In general, the greater the number of indicators, the more comprehensively the SQ can be determined (Nortcliff, 2002). However, when a high correlation exists among the indicators, significant effects may emerge as a problem. Therefore, neglecting some indicators should be considered. However, to select or reject the most suitable indicators, several approaches have been proposed in order to maintain accuracy (Doran and Parkin, 1994; Li and Lindstrom, 2001). Some authors have proposed the use of total data set (TDS) (Doran and Parkin, 1994; Karlen et al., 1997; Larson and Pierce, 1994), whereas others suggest using a selected subset based on correlations among the parameters. The minimum data set (MDS) formed by representative indicators selected by various methods such as multiplevariant regression analysis (Doran and Parkin, 1994; Li and Lindstrom, 2001), principal component analysis (PCA), factor analysis (Brejda et al., 2000b; Shukla et al., 2004), and cluster analysis (Einax and Soldt, 1999) can be effectively used for the determination of SQ (Andrews et al., 2002; Govaerts et al., 2006; Rezaei et al., 2006). Other authors stated that just as in the Delphi data set (DDS) (Zhang et al., 2004), SQ could be determined by using the indicators that are selected according to expert views (Herrick and Jones, 2002).

Although the Çumra Plain is one of the most important fluvial plains in Turkey, there is not sufficient data on the parameters needed to determine SQ in the Middle Eastern Anatolia region in Turkey. In this study, we aimed to select 
the parameters that could be used to establish SQ indexes in the studied region.

\section{Materials and methods}

\subsection{Site description}

The study area (Çumra Plain) is a part of the Great Konya Basin in Konya Province, Turkey, and is located on the Central Anatolian Plateau ( $X$ : 36 467 296-36473 $117 \mathrm{~m}$; $Y$ : 4160910-4 152356m; UTM36N/ED50). The alluvial plains and fans comprise the sediments of several rivers debouching into the southern part of the basin. The alluvial fans or inland deltas consist of sediments ranging from coarse sand to a heavy clay texture (sand $=17.00-61.00 \%$, silt $=11.00-40.00 \%$, clay $=18.00-60.00 \%)($ Driessen and de Meester, 1969). The climate is semiarid with mild summers and very cold winters. The Konya meteorological station's long-term records (1971-2014) show a mean annual precipitation of $296.8 \mathrm{~mm}$, which mostly falls during winter and spring. The total evaporation is $996.6 \mathrm{~mm} \mathrm{year}^{-1}$, the mean annual temperature is $10.8^{\circ} \mathrm{C}$, and the mean annual soil temperature at $50 \mathrm{~cm}$ depth is $13.1^{\circ} \mathrm{C}$ (MGM, 2014). The soil moisture and temperature regimes are xeric and mesic, respectively (Staff, 1999).

Detailed soil investigation reports and maps (1:15000) were used to determine the research area (De Meester, 1970; Meester, 1971, 1970). When determining the study area on this detailed soil map that was prepared at series and phase levels, we considered the prevalence of the soil series. For this reason, the Alibey series, which covered the largest area in the region, was selected as the study area. This series consists of deep loamy-textured soils formed on the main alluvial fan of the May River (De Meester, 1970). It covers an area of approximately 4000 ha, which represents $6 \%$ of the Çumra Plain where irrigated farming (four rotations; cornwheat-sugar and beet-sunflower) is carried out and is approximately $1.023 \mathrm{~m}$ above sea level.

\subsection{Soil sampling and analysis}

The map of the series, including the coordinate information, was created to determine the points where soil samples would be taken. Samplings and measurements were carried out in two sampling periods on 108 parcels of land on which wheat and sugar beets were grown in the years 2013-2014.

A total of 108 soil samples were taken from 10 different points in each parcel at depths of $0-20 \mathrm{~cm}$ and mixed samples were formed for each parcel. Mixed samples taken from the surface to depths of $0-20 \mathrm{~cm}$ depth were divided into three subsamples, each of which weighed $1 \mathrm{~kg}$ (Gugino et al., 2009; Karlen et al., 2003). One of these subsamples was dried, sieved, and used for chemical and physical analyses. The second was kept in the cooler at $+4{ }^{\circ} \mathrm{C}$ for biological analysis. The third subsample was used for the deter- mination of aggregate stability. Soil texture was determined by the Bouyoucos hydrometer method (Gee and Bauder, 1986). Bulk density $(\mathrm{Pb})$ was measured by the core sampling method (Blake and Hartge, 1986). The pycnometer method (Blake and Hartge, 1986) was used to obtain the particle density $(\mathrm{Pk})$ and bulk density and particle density were used to determine porosity $(P)$ (Danielson et al., 1986). Field capacity $(\mathrm{FC})$, was determined at $10 \mathrm{kPa}\left(\mathrm{FC}_{10}\right)$ and $33 \mathrm{kPa}\left(\mathrm{FC}_{33}\right)$ by the pressure plate method (Klute, 1986). The permanent wilting point (PWP) was measured at $1500 \mathrm{kPa}$ pressure (Klute, 1986), and to obtain the available water (AW), the wilting point was deducted from the field capacities $\left(\mathrm{FC}_{10}\right.$ and $\mathrm{FC}_{33}$ ). Aggregate stability (AS) was determined in a rain simulator (Gugino et al., 2009). Penetration resistance was measured using an Eijkelkamp penetrologger, which is pushed under the soil by hand. Upper-layer penetration resistance $\left(\mathrm{PR}_{0-20}\right)$ was measured by taking the averages of the penetration resistance values at $0-20 \mathrm{~cm}$ depth, and lowerlayer penetration resistance $\left(\mathrm{PR}_{20-40}\right)$ was measured by taking the averages of the penetration resistance values at 20$40 \mathrm{~cm}$ depth. $\mathrm{pH}$ measurement was made according to the Comprehensive Assessment of Soil Health (CASH) manual procedure; thus, a $1: 1$ soil : water ratio was used. Electrical conductivity (EC) was measured using an electrical conductivity device in a 1:1 soil and pure water mixture (Kacar, 2009). Total nitrogen was measured using a LECO CN-2000 device with the Dumas dry combustion method (Wright and Bailey, 2001). Ammonium nitrogen $\left(\mathrm{NH}_{4}^{+}-\mathrm{N}\right)$ and nitrate nitrogen $\left(\mathrm{NO}_{3}^{-}-\mathrm{N}\right)$ were measured using the Kjeldahl device (Keeney and Nelson, 1982). Available phosphorus (AP) was determined by the Olsen method (Olsen et al., 1982). Extractable $\mathrm{Ca}, \mathrm{Mg}, \mathrm{Na}$, and $\mathrm{K}$ were extracted using $1 \mathrm{~N}$ ammonium acetate solution, and available $\mathrm{Fe}, \mathrm{Cu}, \mathrm{Mn}$, and $\mathrm{Zn}$ were determined with atomic absorption spectrophotometry through diethylenetriaminepentaacetic acid (DTPA) extraction (Kacar, 2009). Organic matter was determined by using a LECO CN-2000 device with Dumas dry combustion (Wright and Bailey, 2001). Active carbon was determined according to Blair et al. (1995) and Gugino et al. (2009). Potential mineralizable nitrogen (PMN) was measured by Gugino et al. (2009). Roots of germinated bean plants were removed from the soil at the end of the blooming period to determine the root health value (RHV) (Gugino et al., 2009). The following activities were determined: urease enzyme activity (UA) (Hoffmann and Teicher, 1961), catalyzing enzyme activity (CA) (Beck, 1971), dehydrogenase enzyme activity (DA) (Thalmann, 1968), and soil respiration $(R)$ (Isermeyer, 1952). Moreover, mycorrhizal fungi (MSN) were isolated and counted using 30-40× enlarged microscopic images of the fungi in samples prepared by washing them through $38 \mu \mathrm{m}$ sieves (Gerdemann and Nicolson, 1963). 


\subsection{Indicator selection}

Various methods were used to assess SQ and other environmental data, such as multiple-variable regression analysis (Doran and Parkin, 1994; Li and Lindstrom, 2001), PCA, factor analysis (Brejda et al., 2000b; Shukla et al., 2004), discriminant analysis (Brejda et al., 2000a), and cluster analysis (Einax and Soldt, 1999).

First the Kaiser-Meyer-Olkin (KMO) and Bartlett tests (Tatlidil, 2002) were conducted to check whether the data sets that were created based on these properties were in conformity with the PCA.

In the second stage, we used PCA among others to assess and monitor SQ. For this purpose, the total data set was previously divided in three groups to create the MDS from the total of 38 data sets obtained in the study. Physical properties were included in the first group, chemical properties in the second, and biological properties in the third. To determine the potential parameters that could be included in the MDS, MDS recommendations were prepared for each group by considering the component loads determined through PCA, correlation load totals, inter-data correlations, and analysis methods (Andrews et al., 2004; Doran and Jones, 1996; Doran and Parkin, 1994; Karlen et al., 1997).

PCA was conducted for each of four data groups to create the MDS, and correlation matrixes of the data sets were established (Minitab, 1995). When selecting the number of PCs, it is necessary to make selections so that the minimum number of PCs can explain two-thirds (67\%) (Tatlidil, 2002) of the total variance. This percentage can be increased up to $95 \%$. In the PC test, we used the number of PC for which the eigenvalue was $>1$ and which explained two-thirds of the total variance. This is because one of the most commonly accepted rules is to select the number of PCs that meet the number of $R$ matrix or $S$ matrix eigenvalues that are greater than 1 (Tatlidil, 2002). Therefore, the eigenvalues of the matrixes were found, and the same number of PCs were selected as the number of eigenvalues with values greater than 1 . For selecting the PC properties to be used to create the MDS as quality indicators, we accepted as candidates for the MDS those properties whose PC values had the highest percentage in the component cluster for explaining the variance. Properties such as the PC loads, correlation load totals, inter-data correlations, and analysis methods were considered when determining the MDS. When deciding which ones to choose among the properties that are highly correlated, we considered issues such as whether the property would be practical and inexpensive and whether a relationship existed between that property and the other properties.

\section{Results and discussion}

\subsection{General soil properties}

Values of the physical, chemical, and biological properties obtained with the analyses are shown in Table 1 . The textures of soils ranged from sandy clay loam to clay. The average $\mathrm{Pb}$ value was measured to be $1.34 \mathrm{~g} \mathrm{~cm}^{-3}$. The $P_{20-40}$ values were above the limit, while the mean $\mathrm{PR}_{0-20}$ values were not above the root limit value $>300$ PSI (Gugino et al., 2009). All soils had alkaline character. EC value was found to vary between 243 and $1748 \mu \mathrm{S} \mathrm{m}^{-1}$. The salt contents of soils were below $4000 \mu \mathrm{S} \mathrm{m}^{-1}$ and there were no salinity problems. All macro and micronutrient contents of the soil were above the limit value. The organic carbon contents of soils were found to be low.

\subsection{KMO and Bartlett sphericity tests}

KMO and Bartlett test results are shown in Table 2. All properties had values above 0.5 (which confirmed a normal distribution of the data and suitability for the PCA) and passed the KMO and Bartlett tests. The following percentages were obtained at the end of the KMO test: $63.4 \%$ for the physical properties, $66.7 \%$ for the chemical properties, and $62.9 \%$ for the biological properties. The Bartlett test results were significant for all the data sets $(P$ value $0.000<0.05)$. These results showed that the physical, chemical, and biological properties were in conformity with the PCA and showed a high correlation among the variables (Karagöz and Kösterelioğlu, 2015).

\subsection{Indicator selection and creating the minimum data set for physical properties}

The PC analysis and correlation matrix of the selected chemical properties are shown in Fig. 1 and Table 3, respectively. The first PC explained $43.7 \%$, the second PC $20.2 \%$, the third PC $8.9 \%$, and the fourth PC $7.90 \%$ of the variance. As the four PCs explained $80.8 \%$ of the total variance and had an eigenvalue $\geq 1.1113$, these four PCs were selected. The properties that contributed most to the first $\mathrm{PC}$ were sand $(-0.381)$, clay (0.294), $\mathrm{FC}_{10}(0.354), \mathrm{FC}_{33}(0.379)$, and silt (0.294); the properties contributing most to the second PC were $\mathrm{Pb}(-0.457)$ and $P(0.457)$; those contributing most to the third PC were PWP $(-0.564), \mathrm{AWC}_{10}(0.359)$, and $\mathrm{AWC}_{33}$ (0.523); and the properties contributing most to the fourth PC were $\mathrm{PR}_{0-20}(-0.481)$ and $\mathrm{PR}_{20-40}(-0.662)$. All these properties were qualified for selection as candidates for the MDS. However, in order to select the MDS, the component data loads, correlation load totals, inter-data correlations, analysis methods, and applicability were considered.

According to these criteria, the correlation load totals of the candidate data in $\mathrm{PC} 1$ (sand, clay, $\mathrm{FC}_{10}, \mathrm{FC}_{33}$, and silt) were $4.352,3.153,3.897,4.099$, and 4.209 , respectively. It is not possible to change the values of sand and clay in practice and they have no sensitivity against the periodic climate 
Table 1. Soil physical, chemical, and biological properties at sampling sites.

\begin{tabular}{|c|c|c|c|c|c|c|}
\hline Parameters & Variable & & Mean & $\% \mathrm{CV}$ & Min. & Max. \\
\hline \multirow{14}{*}{$\begin{array}{l}\text { Physical } \\
\text { properties }\end{array}$} & Sand & $\%$ & 40.32 & 27.55 & 17.10 & 61.88 \\
\hline & Silt & $\%$ & 25.17 & 24.03 & 11.60 & 40.00 \\
\hline & Clay & $\%$ & 34.52 & 21.76 & 18.05 & 53.53 \\
\hline & $\mathrm{Pb}$ & $\mathrm{g} \mathrm{cm}^{-3}$ & 1.35 & 8.80 & 1.10 & 1.63 \\
\hline & $\mathrm{Pk}$ & $\mathrm{g} \mathrm{cm}^{-3}$ & 2.64 & 0.99 & 2.54 & 2.71 \\
\hline & $P$ & $\%$ & 48.85 & 9.22 & 38.38 & 58.00 \\
\hline & $\mathrm{FC}_{10}$ & $\mathrm{~g} \mathrm{~g}^{-1}$ & 0.32 & 16.55 & 0.22 & 0.46 \\
\hline & $\mathrm{FC}_{33}$ & $\mathrm{~g} \mathrm{~g}^{-1}$ & 0.24 & 17.17 & 0.17 & 0.38 \\
\hline & PWP & $\mathrm{gg}^{-1}$ & 0.14 & 21.92 & 0.10 & 0.25 \\
\hline & $\mathrm{AWC}_{10}$ & $\mathrm{~g} \mathrm{~g}^{-1}$ & 0.18 & 21.61 & 0.09 & 0.29 \\
\hline & $\mathrm{AWC}_{33}$ & $\mathrm{~g} \mathrm{~g}^{-1}$ & 0.10 & 27.36 & 0.04 & 0.20 \\
\hline & $\mathrm{AS}$ & $\%$ & 17.84 & 56.07 & 4.83 & 52.32 \\
\hline & $\mathrm{PR}_{0-20}$ & PSI & 208.08 & 37.70 & 83.00 & 415.00 \\
\hline & $\mathrm{PR}_{20-40}$ & PSI & 314.82 & 31.32 & 147.00 & 689.00 \\
\hline \multirow{15}{*}{$\begin{array}{l}\text { Chemical } \\
\text { properties }\end{array}$} & $\mathrm{pH}$ & - & 8.03 & 1.98 & 7.34 & 8.29 \\
\hline & $\mathrm{EC}$ & $\mu \mathrm{S} \mathrm{m}^{-1}$ & 523.50 & 48.08 & 243.00 & 1748.00 \\
\hline & Lime & $\%$ & 8.97 & 20.33 & 6.47 & 16.48 \\
\hline & $\mathrm{TN}$ & $\%$ & 0.08 & 35.65 & 0.03 & 0.16 \\
\hline & $\mathrm{NH}_{4}-\mathrm{N}$ & $\mathrm{mg} \mathrm{kg}^{-1}$ & 17.13 & 30.56 & 7.00 & 44.89 \\
\hline & $\mathrm{NO}_{3}-\mathrm{N}$ & $\mathrm{mg} \mathrm{kg}^{-1}$ & 25.07 & 83.61 & 3.46 & 129.88 \\
\hline & $\mathrm{AP}$ & $\mathrm{mg} \mathrm{kg}^{-1}$ & 12.97 & 50.80 & 3.36 & 37.79 \\
\hline & $\mathrm{Ca}$ & $\mathrm{mg} \mathrm{kg}^{-1}$ & 5089 & 28.82 & 2622.00 & 8160.00 \\
\hline & $\mathrm{Mg}$ & $\mathrm{mg} \mathrm{kg}^{-1}$ & 818.90 & 53.54 & 220.00 & 1925.00 \\
\hline & $\mathrm{Na}$ & $\mathrm{mg} \mathrm{kg}^{-1}$ & 82.36 & 38.41 & 25.00 & 203.00 \\
\hline & $\mathrm{K}$ & $\mathrm{mg} \mathrm{kg}^{-1}$ & 577.50 & 33.95 & 307.00 & 1356.00 \\
\hline & $\mathrm{Fe}$ & $\mathrm{mg} \mathrm{kg}^{-1}$ & 7.52 & 33.53 & 3.65 & 14.38 \\
\hline & $\mathrm{Cu}$ & $\mathrm{mg} \mathrm{kg}^{-1}$ & 1.29 & 29.61 & 0.45 & 2.06 \\
\hline & $\mathrm{Mn}$ & $\mathrm{mg} \mathrm{kg}^{-1}$ & 15.82 & 38.81 & 5.45 & 25.97 \\
\hline & $\mathrm{Zn}$ & $\mathrm{mg} \mathrm{kg}^{-1}$ & 1.10 & 43.10 & 0.26 & 3.77 \\
\hline \multirow{9}{*}{$\begin{array}{l}\text { Biological } \\
\text { properties }\end{array}$} & $\mathrm{OC}$ & $\%$ & 0.71 & 31.90 & 0.29 & 1.43 \\
\hline & $\mathrm{AC}$ & $\mathrm{mg} \mathrm{kg}^{-1}$ & 486.70 & 49.25 & 96.00 & 996.00 \\
\hline & PMN & $\mu \mathrm{gg}^{-1} \mathrm{w}^{-1}$ & 9.59 & 50.37 & 0.51 & 20.26 \\
\hline & RHV & - & 3.90 & 40.29 & 1.00 & 8.00 \\
\hline & $\mathrm{R}$ & $\operatorname{mg~} 100 \mathrm{~g}^{-1} 24 \mathrm{~h}^{-1}$ & 25.56 & 23.42 & 11.37 & 39.27 \\
\hline & $\mathrm{CA}$ & $\operatorname{mg} 5 g^{-1}$ & 6.56 & 41.33 & 1.87 & 16.20 \\
\hline & UA & $\mu \mathrm{g} \mathrm{g}^{-1}$ & 189.20 & 90.49 & 17.80 & 581.00 \\
\hline & DA & $\mu \mathrm{g} \mathrm{g}^{-1}$ & 2.29 & 69.26 & 0.12 & 5.87 \\
\hline & MSN number & $10 g^{-1}$ & 60.90 & 78.16 & 5.83 & 259.00 \\
\hline
\end{tabular}

$\mathrm{Pb}$, bulk density. $\mathrm{Pk}$, particle density. $P$, porosity. $\mathrm{FC}_{10}$, field capacity $(10 \mathrm{kPa}) . \mathrm{FC}_{33}$, field capacity $(33 \mathrm{kPa}) . \mathrm{PWP}_{10}$, permanent wilting percentage. $\mathrm{AW}_{10}$, available water $(10-1500 \mathrm{kPa}) . \mathrm{AW}_{33}$, available water $(33-1500 \mathrm{kPa})$. AS, aggregate stability. $\mathrm{PR}_{0-20}$, penetration resistance $(0-20 \mathrm{~cm}) . \mathrm{PR}_{20-40}$, penetration resistance $(20-40 \mathrm{~cm})$. TN, total nitrogen. $\mathrm{NH}_{4}-\mathrm{N}$, ammonium nitrogen. $\mathrm{NO}_{3}-\mathrm{N}$, nitrate nitrogen. $\mathrm{AP}$, available phosphorus. OC, organic carbon. AC, active carbon. PMN, potential mineralizable nitrogen. RHV, root health value. $R$, respiration. UA, urease enzyme activity. CA, catalyzing enzyme activity. DA, dehydrogenase enzyme activity. MSN, mycorrhizal fungi. CV, coefficient of variation. Min, minimum. Max, maximum.

and land management changes. Therefore, these two properties were eliminated from the MDS. Among the other three properties, $\mathrm{FC}_{33}$ was the first physical soil property selected for inclusion in the MDS as it had the highest correlation load (4.209), was extensively used, and showed correlation with 11 of the physical properties of soil (Table 4). Furthermore, as the high values of $\mathrm{FC}_{33}$ mean a greater accumu- lation of water in the soils, it is a quality indicator, particularly for dry and semidry regions, to show that plants are less affected by water stress. This will also be valid for other regions considering the cost-effective and sustainable use of water. The candidate $\mathrm{PB}$ and $P$ data for PC2 had inner total correlation loads of 1.994. Because of a high negative correlation between these two candidate properties $\left(R^{2}=-0.994\right.$, 
Table 2. Soil physical, chemical, and biological properties data sets from the Kaiser-Meyer-Olkin and Bartlett sphericity test.

\begin{tabular}{lrrr}
\hline & $\begin{array}{r}\text { Physical } \\
\text { properties }\end{array}$ & $\begin{array}{r}\text { Chemical } \\
\text { properties }\end{array}$ & $\begin{array}{r}\text { Biological } \\
\text { properties }\end{array}$ \\
\hline Kaiser-Meyer-Olkin measure of sampling adequacy & 0.634 & 0.667 & 0.629 \\
Bartlett's test of sphericity approx. chi-square & 3967 & 977 & 453 \\
Sphericity & 91 & 105 & 36 \\
Significance level & 0.000 & 0.000 & 0.000 \\
\hline
\end{tabular}

Table 3. Correlation matrixes of selected physical properties in principal component analysis.

\begin{tabular}{|c|c|c|c|c|c|}
\hline PC1 variables & Sand & Silt & Clay & $\mathrm{FC}_{10}$ & $\mathrm{FC}_{33}$ \\
\hline Sand & & -0.770 & -0.858 & -0.843 & -0.881 \\
\hline Silt & -0.770 & & 0.334 & 0.485 & 0.564 \\
\hline Clay & -0.858 & 0.334 & & 0.856 & 0.849 \\
\hline $\mathrm{FC}_{10}$ & -0.843 & 0.485 & 0.856 & & 0.915 \\
\hline $\mathrm{FC}_{33}$ & -0.881 & 0.564 & 0.849 & 0.915 & \\
\hline Total & 4.352 & 3.153 & 3.897 & 4.099 & $4.209^{*}$ \\
\hline PC2 variables & $\mathrm{Pb}$ & $P$ & & & \\
\hline $\mathrm{Pb}$ & & -0.994 & & & \\
\hline$P$ & -0.994 & & & & \\
\hline Total & $1.994^{*}$ & 1.994 & & & \\
\hline PC3 variables & PWP & $\mathrm{AW}_{10-1500}$ & $\mathrm{AW}_{33-1500}$ & & \\
\hline PWP & & 0.160 & 0.040 & & \\
\hline $\mathrm{AWC}_{10}$ & 0.160 & & 0.821 & & \\
\hline $\mathrm{AWC}_{33}$ & 0.040 & 0.821 & & & \\
\hline Total & 1.200 & $1.981^{*}$ & 1.861 & & \\
\hline PC4 variables & $\mathrm{PR}_{0-20}$ & $\mathrm{PR}_{20-40}$ & & & \\
\hline $\mathrm{PR}_{0-20}$ & & 0.788 & & & \\
\hline $\mathrm{PR}_{20-40}$ & 0.788 & & & & \\
\hline Total & $1.788^{*}$ & $1.788^{*}$ & & & \\
\hline
\end{tabular}

* Selected soil properties as a result of PCA.

$p<0.01$; Table 4) and $P$ was measured from $\mathrm{Pb}, \mathrm{Pb}$ was selected as the second physical property of soil for inclusion in the MDS. The total inner correlation loads of the candidate properties of PC3 (PWP, $\mathrm{AWC}_{10}$, and $\mathrm{AWC}_{33}$ ) were 1.200, 1.981, and 1.861, respectively. As PWP had the lowest total correlation load among these three properties and a high positive correlation existed between $\mathrm{AWC}_{10}$ and $\mathrm{AWC}_{33}\left(R^{2}=\right.$ $0.821, p<0.000$; Table 4), $\mathrm{AWC}_{10}$ was included in the MDS for PC3. As the candidate data of PC4, $\mathrm{PR}_{0-20}$ and $\mathrm{PR}_{20-40}$ indicated the compression at different depths in the soil; both parameters were included in the MDS.

Summarizing, $\mathrm{FC}_{33}, \mathrm{~Pb}, \mathrm{AWC}_{10}, \mathrm{PR}_{0-20}$, and $\mathrm{PR}_{20-40}$ among the physical SQ parameters were included in the MDS, and among these selected properties $\mathrm{Pb}, \mathrm{AWC}_{10}$, $\mathrm{PR}_{0-20}$, and $\mathrm{PR}_{20-40}$ are present in common SQ assessment systems such as the Comprehensive Assessment of Soil Health (CASH) or Soil Management Assessment Framework (SMAF) (Gugino et al., 2009; Karlen et al., 1997). These se- lected physical properties are used in the CASH and SMAF and they were also reported by many researchers as the quality indicators for parameters such as $\mathrm{FC}_{33}$ that are not included in the CASH (Erkossa et al., 2007; Moncada et al., 2014; Rashidi et al., 2010; Sánchez-Navarro et al., 2015; Yang et al., 2010).

\subsection{Indicator selection and creating the minimum data set for chemical properties}

The PC analysis and correlation matrix of the selected chemical properties are shown in Fig. 2 and Table 5, respectively. According to this, the first PC explained 29\%, the second PC $19.4 \%$, the third PC $10.7 \%$, and the fourth PC $8.7 \%$ of the variance. As these four PCs explained $67.8 \%$ of the total variance and had an eigenvalue $\geq 1.3042$, they were selected. The properties that contributed most to the first PC were EC (0.447), lime (0.335), and $\mathrm{Mg}(0.375)$; the proper- 


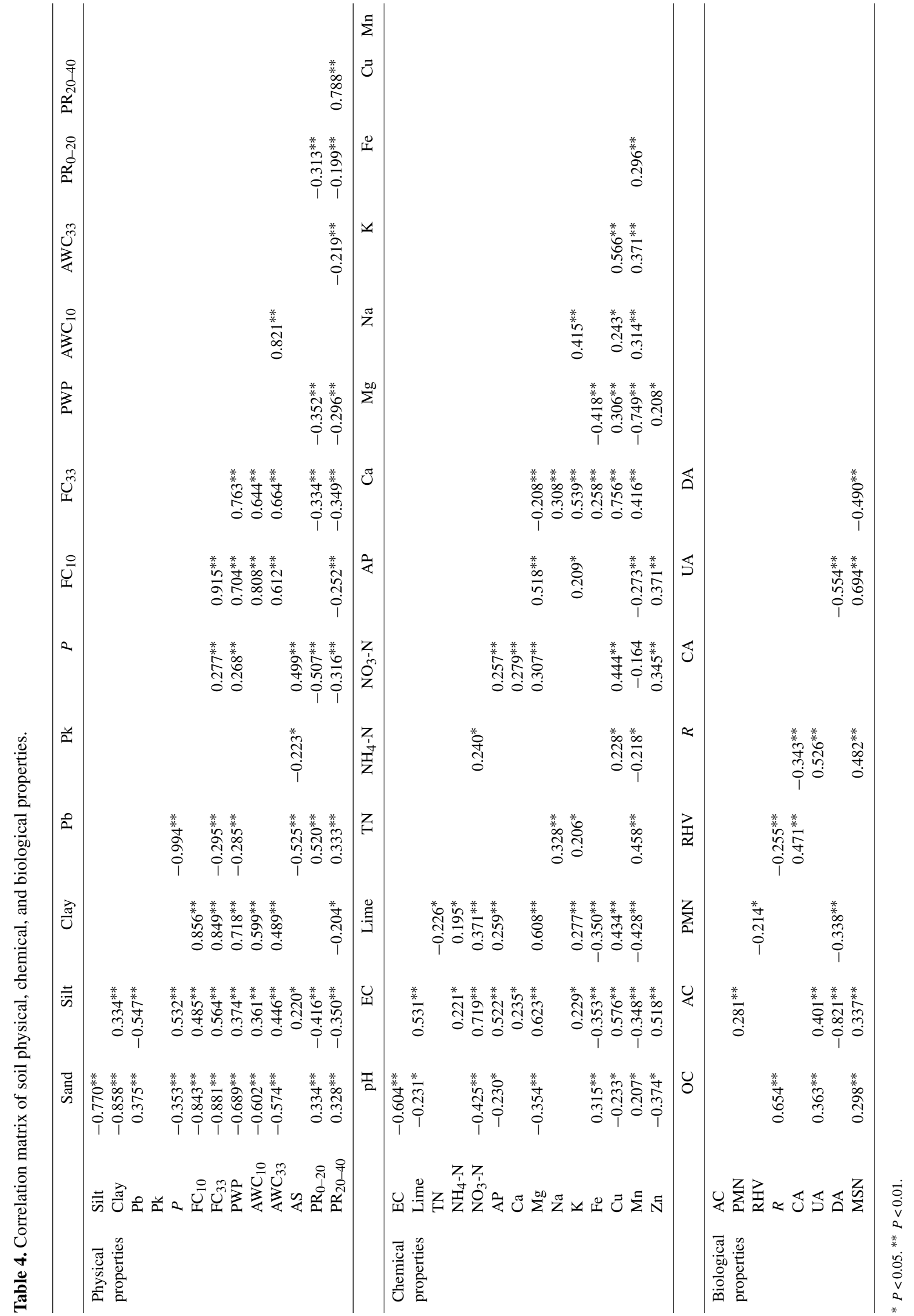




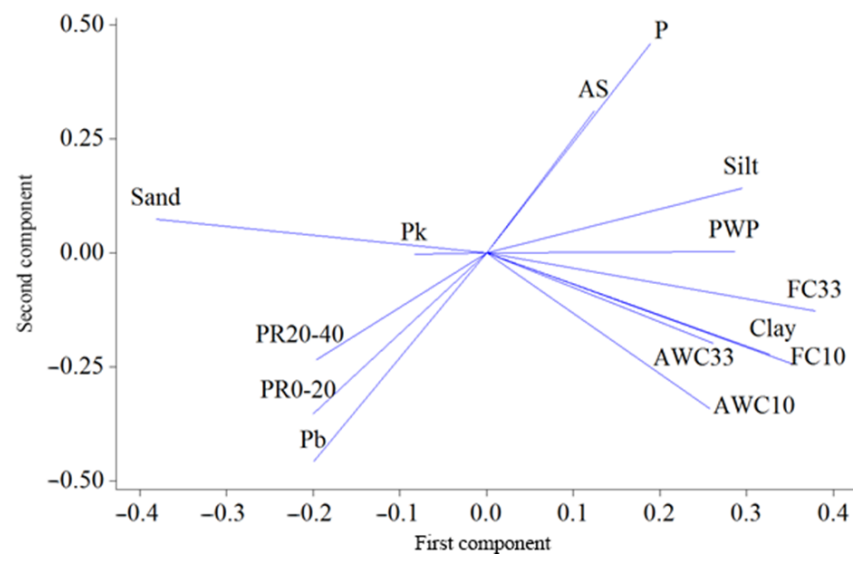

Figure 1. Result of PCA with physical properties of the soils. PCA, principle component analysis; $\mathrm{Pb}$, bulk density; $\mathrm{Pk}$, particle density; $P$, porosity; $\mathrm{FC}_{10}$, field capacity $(10 \mathrm{kPa})$; $\mathrm{FC}_{33}$, field capacity $(33 \mathrm{kPa})$; $\mathrm{PWP}$, permanent wilting percentage; $\mathrm{AW}_{10}$, available water (10-1500 kPa); $\mathrm{AW}_{33}$, available water $(33-1500 \mathrm{kPa})$; AS, aggregate stability; $\mathrm{PR}_{0-20}$, penetration resistance $(0-20 \mathrm{~cm})$; $\mathrm{PR}_{20-40}$, penetration resistance $(20-40 \mathrm{~cm})$.

ties contributing most to the second PC were $\mathrm{Ca}(-0.484)$, $\mathrm{Na}(-0.342), \mathrm{K}(-0.431), \mathrm{Cu}(-0.359)$, and $\mathrm{Mn}(-0.417)$; the properties contributing most to the third $\mathrm{PC}$ were total nitrogen $(\mathrm{TN})(-0.475), \mathrm{AP}(-0.401)$, and $\mathrm{Zn}(-0.411)$; and the properties that contributed most to the fourth PC were $\mathrm{pH}(-0.359)$ and $\mathrm{NO}_{3}-\mathrm{N}(0.381)$. From the order of the PCs obtained from assessing the chemical properties of soils, $\mathrm{EC}$, lime, $\mathrm{Mg}, \mathrm{Ca}, \mathrm{Na}, \mathrm{K}, \mathrm{Cu}, \mathrm{Mn}, \mathrm{TN}, \mathrm{AP}, \mathrm{Zn}, \mathrm{pH}$, and $\mathrm{NO}_{3}-\mathrm{N}$ qualified as candidates for the MDS. The total inner correlation loads of the candidate properties of PC1 (EC, lime, and $\mathrm{Mg}$ ) were $1.585,1.839$, and 1.962 , respectively. It was included in the minimum set together with lime that although the total EC correlation load was lower than the other two properties, as the PC load was higher, the region was located in a dry to semidry climate zone and significant salinization problems existed in certain areas. However, as $\mathrm{Mg}$ was highly correlated with EC $\left(R^{2}=0.623 ; p<0.01\right)$ and lime $_{0-20}\left(R^{2}=0.608 ; p<0.01\right)$ (Table 4$)$ and the Mg scopes of the soils subject to the study were above the sufficiency level in all samples, it was not included in the MDS.

The total inner correlation loads of the candidate properties of PC2 (Ca, $\mathrm{Na}, \mathrm{K}, \mathrm{Cu}$, and $\mathrm{Mn})$ were $3.019,2.280$, 2.891, and 2.131, respectively. As Ca had the highest total correlation load among these five properties and $\mathrm{Mn}$ remained below the level of sufficiency in certain samples (<14.0 mg Mn kg-1; FAO, 1990), it was included in the MDS. However, as the $\mathrm{Cu}$ and $\mathrm{K}$ contents of the soils were above the level of sufficiency in all samples (>0.2 $\mathrm{mg} \mathrm{Cu} \mathrm{kg}^{-1}$; Follett, 1969; > $110 \mathrm{mg} \mathrm{K} \mathrm{kg}^{-1}$; FAO, $1990)$ and Na was not a nutrient element, it was not included in the MDS. The total inner correlation loads of the candidate properties of $\mathrm{PC} 3$ (TN, AP, and $\mathrm{Zn}$ ) were 1.244, 1.543, and

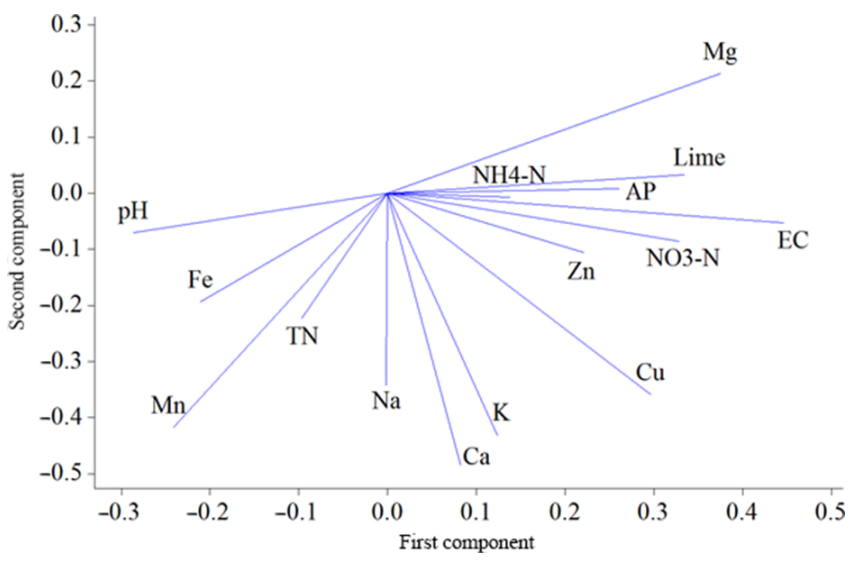

Figure 2. Result of PCA with chemical properties of the soils. PCA, principle component analysis; $\mathrm{TN}$, total nitrogen; $\mathrm{NH}_{4}-\mathrm{N}$, ammonium nitrogen; $\mathrm{NO}_{3}-\mathrm{N}$, nitrate nitrogen; $\mathrm{AP}$; available phosphorus.

Table 5. Correlation matrixes of the selected chemical properties in principal component analysis.

\begin{tabular}{|c|c|c|c|c|c|}
\hline PC1 variables & $\mathrm{EC}$ & Lime & $\mathrm{Mg}$ & & \\
\hline $\mathrm{EC}$ & & -0.231 & -0.354 & & \\
\hline Lime & -0.231 & & 0.608 & & \\
\hline $\mathrm{Mg}$ & -0.354 & 0.608 & & & \\
\hline Total & $1.585^{*}$ & $1.839^{*}$ & $1.962^{*}$ & & \\
\hline PC2 variables & $\mathrm{Ca}$ & $\mathrm{Na}$ & K & $\mathrm{Cu}$ & $\mathrm{Mn}$ \\
\hline $\mathrm{Ca}$ & & 0.308 & 0.539 & 0.756 & 0.416 \\
\hline $\mathrm{Na}$ & 0.308 & & 0.415 & 0.243 & 0.314 \\
\hline $\mathrm{K}$ & 0.539 & 0.415 & & 0.566 & 0.371 \\
\hline $\mathrm{Cu}$ & 0.756 & 0.243 & 0.566 & & 0.030 \\
\hline $\mathrm{Mn}$ & 0.416 & 0.314 & 0.371 & 0.030 & \\
\hline Total & $3.019^{*}$ & 2.280 & 2.891 & 2.595 & $2.131^{*}$ \\
\hline PC3 variables & $\mathrm{TN}$ & AP & $\mathrm{Zn}$ & & \\
\hline $\mathrm{TN}$ & & 0.172 & 0.072 & & \\
\hline $\mathrm{AP}$ & 0.172 & & 0.371 & & \\
\hline $\mathrm{Zn}$ & 0.072 & 0.371 & & & \\
\hline Total & $1.244^{*}$ & $1.543^{*}$ & $1.443^{*}$ & & \\
\hline PC4 variables & $\mathrm{pH}$ & $\mathrm{NO}_{3}-\mathrm{N}$ & & & \\
\hline $\mathrm{pH}$ & & -0.425 & & & \\
\hline $\mathrm{NO}_{3}-\mathrm{N}$ & -0.425 & & & & \\
\hline Total & $1.425^{*}$ & $1.425^{*}$ & & & \\
\hline
\end{tabular}

* Selected soil properties as a result of PCA.

1.443 , respectively. No significant correlation existed among these three properties, $\mathrm{Zn}$ remained below the sufficiency level (>0.7 $\mathrm{mg} \mathrm{Zn} \mathrm{kg}^{-1}$ presence; FAO, 1990), $P$ was an important macronutrient element, and $\mathrm{TN}$ remained below the sufficiency level in most of the soils studied $(<0.09 \% \mathrm{~N})$; thus, they were included in the MDS for TN, AP, and Zn. The total inner correlation load of the candidate properties of $\mathrm{pH}$ and $\mathrm{NO}_{3}-\mathrm{N}$ was 1.425 . Soil $\mathrm{pH}$ directly affects the usefulness of the nutrient elements. $\mathrm{NO}_{3}-\mathrm{N}$ was lacking in our 
soils, and when it is excessive, it might cause environmental health problems; it was therefore included in the MDS. Similarly, $\mathrm{pH}, \mathrm{AP}, \mathrm{Mn}$, and $\mathrm{Zn}$ in CASH and SMAF were also accepted as SQ parameters (Andrews et al., 2004; Gugino et al., 2009). To summarize, EC, lime, $\mathrm{Mg}, \mathrm{Ca}, \mathrm{Mn}, \mathrm{TN}$, $\mathrm{AP}, \mathrm{Zn}, \mathrm{pH}$, and $\mathrm{NO}_{3}-\mathrm{N}$, among the chemical SQ parameters, were selected as the variables that could be included in MDS. Most of these selected properties are also used as quality criteria in the CASH and SMAF. Several other researchers reported that lime, $\mathrm{Ca}, \mathrm{TN}$, and $\mathrm{NO}_{3}-\mathrm{N}$ that are not used in these assessment systems could be used as quality indicators (Baridón and Casas, 2014; Benintende et al., 2015; Liu et al., 2014; Mojiri et al., 2011; Sánchez-Navarro et al., 2015; Shirani et al., 2015; Viana et al., 2014; Zdruli et al., 2014).

\subsection{Indicator selection and creating the minimum data set for biological properties}

The PC analysis and correlation matrix of the selected biological properties are shown in Fig. 3 and Table 6, respectively. The first PC explained $34 \%$, the second PC $23.2 \%$, and the third PC $15.3 \%$ of the variance. As the three PCs explained $72.5 \%$ of the total variance and had an eigenvalue $\geq 1.3738$, these three PCs were selected. The properties that contributed most to the first PC were the amounts of UA (0.486), DA (-0.412), and MSN (0.461); properties that contributed most to the second PC were OC $(-0.410)$, $\mathrm{AC}(0.411)$, and $R(-0.426)$; properties that contributed most to the third PC were PMN (0.584), RHV $(-0.506)$, and CA $(-0.380)$, and these became candidates for MDS. The total inner correlation loads of the candidate properties of PC1, the levels of UA, DA, and MSN, were 2.248, 2.044, and 2.184, respectively. As urease had the highest total correlation load among these properties, UA was included in the MDS for PC1. Although DA was the second property with the highest correlation total, due to the presence of significant correlations between both DA and UA and between DA and AC and the difficulty of determining the amount of MSN, the latter two properties were not included in the MDS. The properties that contributed the most to $\mathrm{PC} 2$ were $\mathrm{OC}, \mathrm{AC}$, and $R$. The correlation load totals of these were 1.680, 1.043, and 1.671, respectively. Among these properties, $R$ and OC, which had the highest PC coefficients, were included in the minimum set for PC2. Only PMN, RHV, and CA were selected as candidates for the PC3 data set. The correlation load totals of PMN, RHV, and CA were $1.269,1.685$, and 1.526 , respectively. They were included in the MDS since the highest correlation load total was in the RHV. According to the results obtained, OC and R were accepted as SQ parameters in the $\mathrm{CASH}$, and $\mathrm{OC}$ and $\mathrm{R}$ were accepted as SQ parameters in the SMAF (Andrews et al., 2004; Gugino et al., 2009; MoebiusClune et al., 2011). Though urease activity among these selected properties is not listed in the CASH or SMAF, many other researchers reported that these could be used as quality

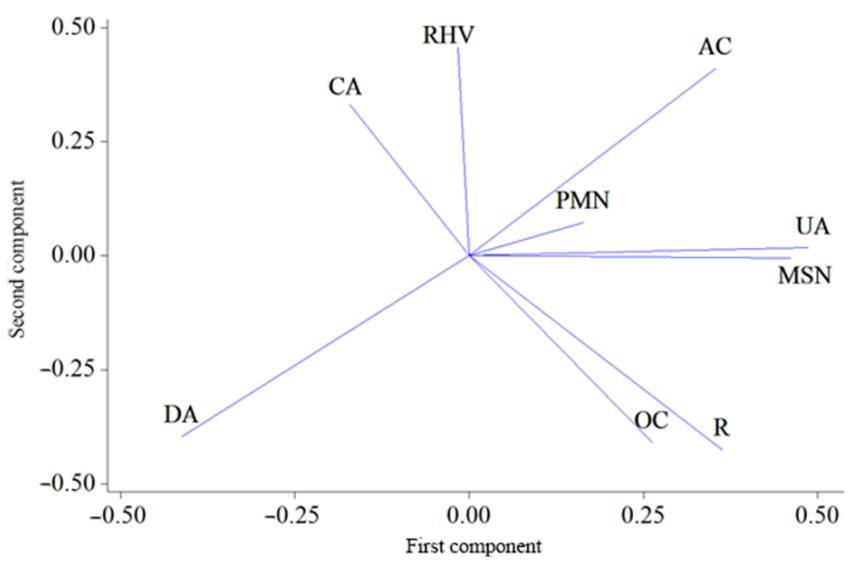

Figure 3. Result of PCA with biological properties of the soils. PCA, principle component analysis; OC, organic carbon; AC, active carbon; PMN, potential mineralizable nitrogen; RHV, root health value; $R$, respiration; UA, urease enzyme activity; CA, catalyzing enzyme activity; DA, dehydrogenase enzyme activity; MSN, mycorrhizal fungi.

Table 6. Correlation matrixes of the selected biological properties in principal component analysis.

\begin{tabular}{lrrr}
\hline PC1 variables & UA & DA & MSN \\
\hline UA & & -0.554 & 0.694 \\
DA & -0.554 & & -0.490 \\
MSN & 0.694 & -0.490 & \\
Total & $2.248^{*}$ & 2.044 & 2.184 \\
\hline PC2 variables & OC & AC & $R$ \\
\hline OC & & -0.026 & 0.654 \\
AC & -0.026 & & 0.017 \\
$R$ & 0.654 & 0.017 & \\
Total & $1.680^{*}$ & $1.043^{*}$ & $1.671^{*}$ \\
\hline PC3 variables & PMN & RHV & CA \\
\hline PMN & & -0.214 & -0.055 \\
RHV & -0.214 & & 0.471 \\
CA & -0.055 & 0.471 & \\
Total & 1.269 & $1.685^{*}$ & 1.526 \\
\hline
\end{tabular}

* Selected soil properties as a result of PCA

indicators (Baridón and Casas, 2014; Benintende et al., 2015; Masto et al., 2007; Saviozzi et al., 2001).

\section{Conclusions}

This paper discusses the parameters that could be used to monitor the SQ in the Konya Çumra region, one of the most important agricultural areas in Turkey. This study is crucial for sustainable land management in the region as there is a serious lack of studies in this area assessing soil characteristics that can serve as soil quality indicators. 
The study revealed the physical, chemical, and biological parameters that could be used to assess the SQ in the study area and in other areas. The MDS was created for the selection of indicators using the $\mathrm{PC}$ analysis for this purpose. $\mathrm{FC}_{33}, \mathrm{~Pb}, \mathrm{AW}_{10}, \mathrm{PR}_{0-20}$, and $\mathrm{PR}_{20-40}$ among the physical properties; EC, $\mathrm{Mg}$, lime, $\mathrm{Ca}, \mathrm{Mn}, \mathrm{TN}, \mathrm{AP}, \mathrm{Zn}, \mathrm{pH}$, and $\mathrm{NO}_{3}$ $\mathrm{N}$ among the chemical properties; and $\mathrm{UA}, \mathrm{OC}, R$, and root health among the biological properties were selected as indicators that could be used in the assessment of SQ. Score functions for the properties that exist in the CASH and SMAF among these parameters can be used in scoring. Conversely, other parameters such as $\mathrm{FC}_{33}$, lime, $\mathrm{Ca}, \mathrm{TN}, \mathrm{NO}_{3}-\mathrm{N}$, and urease were also found to be suitable for use in assessing SQ. Consequently, scoring functions of these properties must be developed. In this study, the MDS method and principal component analysis were found to be appropriate statistical methods to select the quality indicators. This study evidenced that the selected properties could be used in determination and monitoring of soil quality and that PCA is the appropriate method for parameter selection in similar ecosystems in central Anatolia.

Data availability. The data used in this article will be available on the TUBITAK project results page once they have been published.

Competing interests. The authors declare that they have no conflict of interest.

Acknowledgements. This study was taken from a research project supported by TUBITAK (Scientific and Technological Research Council of Turkey, project no. TOVAG 112O314) and Selçuk University (S.U.) BAP Office (Coordinating Office of Scientific Research Projects, project no. 09201086). The authors would like to thank the TUBITAK and S.U. BAP staff.

Edited by: M. Muñoz-Rojas

Reviewed by: R. Wang and one anonymous referee

\section{References}

Andrews, S., Karlen, D., and Mitchell, J.: A comparison of soil quality indexing methods for vegetable production systems in Northern California, Agr. Ecosyst. Environ., 90, 25-45, 2002.

Andrews, S. S., Karlen, D. L., and Cambardella, C. A.: The soil management assessment framework, Soil Sci. Soc. Am. J., 68, 1945-1962, 2004.

Aparicio, V. and Costa, J. L.: Soil quality indicators under continuous cropping systems in the Argentinean Pampas, Soil Till. Res., 96, 155-165, 2007.

Aronson, J., Floret, C., Floc'h, E., Ovalle, C., and Pontanier, R.: Restoration and Rehabilitation of Degraded Ecosystems in Arid and Semi-Arid Lands. I. A View from the South, Restor. Ecol., 1, 8-17, 1993.
Arshad, M. and Coen, G.: Characterization of soil quality: physical and chemical criteria, Am. J. Alternative Agr., 7, 25-31, 1992.

Arshad, M. A. and Martin, S.: Identifying critical limits for soil quality indicators in agro-ecosystems, Agr. Ecosyst. Environ., 88, 153-160, 2002.

Baridón, J. E. and Casas, R. R.: Quality indicators in subtropical soils of Formosa, Argentina: Changes for agriculturization process, International Soil and Water Conservation Research, 2, 1324, 2014.

Beck, T.: Die Messung der Katalaseaktivitaet von Böden, Z. Pflanz. Bodenkunde, 130, 68-81, 1971.

Benintende, S., Benintende, M., Sterren, M., Saluzzio, M., and Barbagelata, P.: Biological variables as soil quality indicators: Effect of sampling time and ability to classify soils by their suitability, Ecol. Indic., 52, 147-152, 2015.

Bindraban, P., Stoorvogel, J., Jansen, D., Vlaming, J., and Groot, J.: Land quality indicators for sustainable land management: proposed method for yield gap and soil nutrient balance, Agr. Ecosyst. Environ., 81, 103-112, 2000.

Blair, G. J., Lefroy, R. D., and Lisle, L.: Soil carbon fractions based on their degree of oxidation, and the development of a carbon management index for agricultural systems, Crop Pasture Sci., 46, 1459-1466, 1995.

Blake, G. and Hartge, K.: Particle density, in: Methods of Soil Analysis: Part 1 - Physical and Mineralogical Methods, Soil Science Society of America, American Society of Agronomy, Madison, WI, 377-382, 1986.

Brandt, C. J. and Thornes, J. B.: Mediterranean desertification and land use, John Wiley \& Sons Ltd, Chichester, 1996.

Brejda, J. J., Karlen, D. L., Smith, J. L., and Allan, D. L.: Identification of regional soil quality factors and indicators, II. Northern Mississippi Loess Hills and Palouse Prairie, Soil Sci. Soc. Am. J., 64, 2125-2135, 2000a.

Brejda, J. J., Moorman, T. B., Karlen, D. L., and Dao, T. H.: Identification of regional soil quality factors and indicators, I. Central and Southern High Plains, Soil Sci. Soc. Am. J., 64, 2115-2124, 2000 b.

Burger, J. A. and Kelting, D. L.: Soil quality monitoring for assessing sustainable forest management, in: The contribution of soil science to the development of and implementation of criteria and indicators of sustainable forest management, Soil Science Society of America, American Society of Agronomy, Madison, WI, 1998, 17-52, 1998.

Chen, Z. S.: Selecting indicators to evaluate the soil quality of Taiwan soils and approaching the national level of sustainable soil management, in: Proceedings of the International Seminar on Soil Management for Sustainable Agriculture in the Tropics, 1419 December 1998, Taichung, Taiwan, ROC, 131-171, FFTC ASPAC, 1998.

Danielson, R., Sutherland, P., and Klute, A.: Porosity, in: Methods of soil analysis. Part 1. Physical and mineralogical methods, Soil Science Society of America, American Society of Agronomy, Madison, Wisconsin, 443-461, 1986.

De Meester, T.: Soils of the Great Konya Basin, Turkey, Agric. Res. Rep., Centre for Agricultural Publishing and Documentation, Wageningen, the Netherlands, 740, 290, 1970.

Dick, R. P., Breakwell, D. P., and Turco R. F.: Soil Enzyme Activities and Biodiversity Measurements as Integrative Microbiological Indicators, in: Doran, J. W. and Jones, A. J., Methods for 
Assessing Soil Quality, SSSA Spec. Publ., 49, SSSA, Madison, WI, 247-271, doi:10.2136/sssaspecpub49.c15, 1996.

Doran, J., Safley, M., Pankhurst, C., Doube, B., and Gupta, V.: Defining and assessing soil health and sustainable productivity, in: Biological indicators of soil health, CAB International, Wallingford, UK, 1-28, 1997.

Doran, J. W.: Soil health and global sustainability: translating science into practice, Agr. Ecosyst. Environ., 88, 119-127, 2002.

Doran, J. W. and Jones, A. J.: Methods for assessing soil quality, Soil Science Society of America Inc., Madison, Wisconsin, USA, 1996.

Doran, J. W. and Parkin, T. B.: Defining and Assessing Soil Quality, in: Defining Soil Quality for a Sustainable Environment, edited by: Doran, J. W., Coleman, D. C., Bezdicek, D. F., and Stewart, B. A., SSSA Spec. Publ., 35, SSSA and ASA, Madison, WI, 121, doi:10.2136/sssaspecpub35.c1, 1994.

Doran, J. W. and Zeiss, M. R.: Soil health and sustainability: managing the biotic component of soil quality, Appl. Soil Ecol., 15, $3-11,2000$.

Doran, J. W., Parkin, T. B., and Jones, A.: Quantitative indicators of soil quality: a minimum data set, in: Methods for assessing soil quality, Madison, Wisconsin, USA, 25-37, 1996.

Driessen, P. and de Meester, T.: Soils of the Cumra area, Centre for Agricultural Publishing and Documentation, Wageningen, the Netherlands, 1969.

Dumanski, J. and Pieri, C.: Land quality indicators: research plan, Agr. Ecosyst. Environ., 81, 93-102, 2000.

Einax, J. and Soldt, U.: Geostatistical and multivariate statistical methods for the assessment of polluted soils - merits and limitations, Chemometr. Intell. Lab., 46, 79-91, 1999.

El-Ramady, H. R., Alshaal, T., Amer, M., Domokos-Szabolcsy, É., Elhawat, N., Prokisch, J., and Fári, M.: Soil quality and plant nutrition, in: Sustainable Agriculture Reviews 14, Springer, Switzerland, 345-447, 2014.

Erkossa, T., Itanna, F., and Stahr, K.: Indexing soil quality: a new paradigm in soil science research, Soil Res., 45, 129-137, 2007.

Eswaran, H., Lal, R., and Reich, P.: Land degradation: an overview, in: Responses to Land degradation, Oxford Press, New Delhi, India, 20-35, 2001.

FAO: Micronutrient Assessment at The Country Level, 1-208, An international study, edited by: Sillanpa, M., FAO Soil Bulletin 63, FAO, Rome, Italy, 1990.

Fauci, M. F. and Dick, R. P.: Microbial biomass as an indicator of soil quality: Effects of long-term management and recent soil amendments, Defining soil quality for a sustainable environment, SSSA and ASA, Madison, WI, 229-234, 1994.

Fernandes, J. C., Gamero, C. A., Rodrigues, J. G. L., and MirásAvalos, J. M.: Determination of the quality index of a Paleudult under sunflower culture and different management systems, Soil Till. Res., 112, 167-174, 2011.

Follett, R. H.: Zn, Fe, Mn, and $\mathrm{Cu}$, in: Colorado soils, Colorado State University, Fort Collins, 1969.

Gee, G. and Bauder, J.: Particle-size analysis, in: Methods of soil analysis, Part 1. American society of Agronomy, edited by: Klute, A., Inc., Ma, SSSA Book Ser. 5.1, SSSA, ASA, Madison, WI, 383-411, doi:10.2136/sssabookser5.1.2ed.c15, 1986.

Gerdemann, J. and Nicolson, T. H.: Spores of mycorrhizal Endogone species extracted from soil by wet sieving and decanting, $\mathrm{T}$. Brit. Mycol. Soc., 46, 235-244, 1963.
Govaerts, B., Sayre, K. D., and Deckers, J.: A minimum data set for soil quality assessment of wheat and maize cropping in the highlands of Mexico, Soil Till. Res., 87, 163-174, 2006.

Gregorich, E., Monreal, C., Carter, M., Angers, D., and Ellert, B.: Towards a minimum data set to assess soil organic matter quality in agricultural soils, Can. J. Soil Sci., 74, 367-385, 1994.

Gugino, B. K., Abawi, G. S., Idowu, O. J., Schindelbeck, R. R., Smith, L. L., Thies, J. E., Wolfe, D. W., and Van Es, H. M.: Cornell soil health assessment training manual, Cornell University College of Agriculture and Life Sciences, Cornell University, Geneva, NY, 2009.

Harris, R. F., Karlen, D. L., Mulla, D. J., Doran, J., and Jones, A.: A conceptual framework for assessment and management of soil quality and health, in: Methods for assessing soil quality, Soil Science Society of America, Special Publication No. 49, 61-82, 1996.

Herrick, J. E. and Jones, T. L.: A dynamic cone penetrometer for measuring soil penetration resistance, Soil Sci. Soc. Am. J., 66, 1320-1324, 2002.

Hoffmann, G. and Teicher, K.: Ein kolorimetrisches Verfahren zur Bestimmung der Ureaseaktivität in Böden, Z. Pflanz. Bodenkunde, 95, 55-63, 1961.

Hueso-González, P., Martínez-Murillo, J. F., and Ruiz-Sinoga, J. D.: The impact of organic amendments on forest soil properties under Mediterranean climatic conditions, Land Degrad. Dev., 25, 604-612, 2014.

Isermeyer, H.: Eine einfache Methode zur Bestimmung der Bodenatmung und der Karbonate im Boden, Z. Pflanz. Bodenkunde, 56, 26-38, 1952.

Kacar, B.: Toprak analizleri, Nobel Yayın Dağıtı m, Ankara, Nobel bilim ve araştırma merkezi, 2009 (in Turkish).

Karagöz, Y. and Kösterelioğlu, İ.: İletişim becerileri değerlendirme ölçeğinin faktör analizi metodu ile geliştirilmesi, Dumlupınar Üniversitesi Sosyal Bilimler Dergisi, Kütahya, 21, 81-97 2015.

Karlen, D., Mausbach, M., Doran, J., Cline, R., Harris, R., and Schuman, G.: Soil quality: a concept, definition, and framework for evaluation (a guest editorial), Soil Sci. Soc. Am. J., 61, 4-10, 1997.

Karlen, D. L., Ditzler, C. A., and Andrews, S. S.: Soil quality: why and how?, Geoderma, 114, 145-156, 2003.

Karlen, D. L., Birell, S. J., and Hess, J. R.: A five-year assessment of corn stover harvest in central Iowa, USA, Soil Till. Res., 115, 47-55, 2011.

Kay, B. D. and Grant, C. D.: Suctural aspects of soil quality, in: Soil Quality is in the Hands of the Land Manager, edited by: MacEwan, R. J. and Carter, M. R., Proceedings of an International Symposium, Advances in Soil Quality for Land Management: Science, Practice and Policy, 17-19 April 1996, University of Ballarat, Ballarat, Victoria, Australia, 37-41, 1996.

Keeney, D. R. and Nelson, D.: Nitrogen - inorganic forms, in: Methods of soil analysis. Part 2. Chemical and microbiological properties, Soil Science Society of America, American Society of Agronomy, Madison, WI, 643-698, 1982.

Klute, A.: Water retention: laboratory methods, in: Methods of Soil Analysis: Part 1 - Physical and Mineralogical Methods, Soil Science Society of America, American Society of Agronomy, Madison, WI, 635-662, 1986.

Larson, W. E. and Pierce F. J.: Conservation and enhancement of soil quality, in: Evaluation for Sustainable Land Management 
in the Developing World, edited by: Dumanski, J., Proceedings of the International Workshop, Chiang Rai, Thailand, 1521 September 1991, Technical Papers, 2, International Board for Soil Resource and Management, Bangkok, Thailand, 175-203, 1991.

Larson, W. E. and Pierce, F. J.: The dynamics of soil quality as a measure of sustainable management, in: Defining soil quality for a sustainable environment, Soil Science Society of America, American Society of Agronomy, Madison, WI, 37-51, 1994.

Li, Y. and Lindstrom, M.: Evaluating soil quality-soil redistribution relationship on terraces and steep hillslope, Soil Sci. Soc. Am. J., 65, 1500-1508, 2001.

Lima, A., Brussaard, L., Totola, M., Hoogmoed, W., and De Goede, R.: A functional evaluation of three indicator sets for assessing soil quality, Appl. Soil Ecol., 64, 194-200, 2013.

Linden, D. R., Hendrix, P. F., Coleman, D. C., and van Vliet, P. C.: Faunal indicators of soil quality, in: Defining soil quality for a sustainable environment, SSSA Special Publication, Madison, 91-106, 1994.

Liu, Z., Zhou, W., Shen, J., Li, S., He, P., and Liang, G.: Soil quality assessment of Albic soils with different productivities for eastern China, Soil Till. Res., 140, 74-81, 2014.

Masto, R. E., Chhonkar, P. K., Singh, D., and Patra, A. K.: Soil quality response to long-term nutrient and crop management on a semi-arid Inceptisol, Agr. Ecosyst. Environ., 118, 130-142, 2007.

McGrath, D. and Zhang, C.: Spatial distribution of soil organic carbon concentrations in grassland of Ireland, Appl. Geochem., 18, 1629-1639, 2003.

Meester, T. D.: Soils of the Great Konya Basin, Turkiye, Pudoc, Centre for Agricultural Publishing and Documentation, Wageningen, the Netherlands, 1970.

Meester, T. D.: Highly calcareous lacustrine soils in the Great Konya Basin, Turkey, Pudoc, Wageningen, the Netherlands, 1971.

MGM: Müdürlüğü, Meteoroloji Genel İklim Verileri. Meteoroloji Genel Müdürlüğü, Ankara, Turkey, 2014.

Minitab: Minitab reference manual (Release 7.1), Minitab Inc., State Coll PA, 16801, USA, 1995.

Moebius-Clune, B., Idowu, O., Schindelbeck, R., Van Es, H., Wolfe, D., Abawi, G., and Gugino, B.: Developing standard protocols for soil quality monitoring and assessment, in: Innovations as key to the green revolution in Africa, Springer, Netherlands, 833842, 2011.

Mojiri, A., Kazemi, Z., and Amirossadat, Z.: Effects of land use changes and hillslope position on soil quality attributes (A case study: Fereydoonshahr, Iran), Afr. J. Agric. Res., 6, 1114-1119, 2011.

Moncada, M. P., Gabriels, D., and Cornelis, W. M.: Data-driven analysis of soil quality indicators using limited data, Geoderma, 235, 271-278, 2014.

Muñoz-Rojas, M., Erickson, T. E., Martini, D., Dixon, K. W., and Merritt, D. J.: Soil physicochemical and microbiological indicators of short, medium and long term post-fire recovery in semiarid ecosystems, Ecol. Indic., 63, 14-22, 2016 a.

Muñoz-Rojas, M., Erickson, T. E., Dixon, K. W., and Merritt, D. J.: Soil quality indicators to assess functionality of restored soils in degraded semiarid ecosystems, Restoration Ecology, 24, 43-53, 2016 b.
Nortcliff, S.: Standardisation of soil quality attributes, Agr. Ecosyst. Environ., 88, 161-168, 2002.

Olsen, S., Sommers, L., and Page, A.: Methods of soil analysis. Part 2, Agron. Monogr., 9, 403-430, 1982.

Özulu, M., Özaytekin, H. H., and Uyanöz, R.: Toprak Kalitesinin Değerlendirilmesinde Farklı Yaklaşımlar, Selçuk Tarı m Bilimleri Dergisi, 20, 1-8, 2006.

Powers, R. F., Tiarks, P., and Boyle, J. R.: Assessing soil quality: practicable standards for sustainable forest productivity in the United States, in: The contribution of soil science to the development of and implementation of criteria and indicators of sustainable forest management, Soil Science Society of America Special Publication, Madison, 53-80, 1998.

Qi, Y., Darilek, J. L., Huang, B., Zhao, Y., Sun, W., and Gu, Z.: Evaluating soil quality indices in an agricultural region of Jiangsu Province, China, Geoderma, 149, 325-334, 2009.

Rasheed, S., Li, Z., Xu, D., and Kovacs, A.: Presence of cell-free human immunodeficiency virus in cervicovaginal secretions is independent of viral load in the blood of human immunodeficiency virus-infected women, Am. J. Obstet. Gynecol., 175, 122-130, 1996.

Rashidi, M., Seilsepour, M., Ranjbar, I., Gholami, M., and Abbassi, S.: Evaluation of some soil quality indicators in the Varamin region, Iran, World Applied Sciences Journal, 9, 101-108, 2010.

Reganold, J. P. and Palmer, A. S.: Significance of gravimetric versus volumetric measurements of soil quality under biodynamic, conventional, and continuous grass management, J. Soil Water Conserv., 50, 298-305, 1995.

Rezaei, S. A., Gilkes, R. J., and Andrews, S. S.: A minimum data set for assessing soil quality in rangelands, Geoderma, 136, 229_ 234, 2006.

Rice, C. W., Moorman, T. B., and Beare, M.: Role of microbial biomass carbon and nitrogen in soil quality, in: Methods for assessing soil quality, Soil Science Society of America, Inc, Madison, Wisconsin, USA, 203-215, 1996.

Sánchez-Navarro, A., Gil-Vázquez, J., Delgado-Iniesta, M., MarínSanleandro, P., Blanco-Bernardeau, A., and Ortiz-Silla, R.: Establishing an index and identification of limiting parameters for characterizing soil quality in Mediterranean ecosystems, Catena, 131, 35-45, 2015.

Saviozzi, A., Levi-Minzi, R., Cardelli, R., and Riffaldi, R.: A comparison of soil quality in adjacent cultivated, forest and native grassland soils, Plant Soil, 233, 251-259, 2001.

Shirani, H., Habibi, M., Besalatpour, A., and Esfandiarpour, I.: Determining the features influencing physical quality of calcareous soils in a semiarid region of Iran using a hybrid PSO-DT algorithm, Geoderma, 259, 1-11, 2015.

Shukla, M., Lal, R., and Ebinger, M.: Soil quality indicators for the north Appalachian experimental watersheds in Coshocton Ohio, Soil Sci., 169, 195-205, 2004.

Sinha, N. K., Chopra, U. K., Singh, A. K., Mohanty, M., Somasundaram, J., and Chaudhary, R.: Soil Physical Quality as Affected by Management Practices Under Maize-Wheat System, Natl. Acad. Sci. Lett., 37, 13-18, 2014.

Staff, S. S.: Keys to soil taxonomy, Soil Conservation Service, Natural Resources Conservation Service, United States Department of Agriculture, Washington, 1999.

Tatlidil, H.: Uygulamali çok degiskenli istatistiksel analiz, Cem Web Ofset Ltd. Sti, Ankara, Turkey, 424, 2002. 
Thalmann, A.: Zur Methodik der bestimmung der dehydrogenaseaktivität im boden mittels triphenyltetrazoliumchlorid (TTC), Landwirt. Forsch., 21, 249-258, 1968.

Turco, R., Kennedy, A., and Jawson, M.: Microbial indicators of soil quality, Purdue Univ., Lafayette, IN, USA, 1992.

Viana, R. M., Ferraz, J. B., Neves, A. F., Vieira, G., and Pereira, B. F.: Soil quality indicators for different restoration stages on Amazon rainforest, Soil Till. Res., 140, 1-7, 2014.

Wright, A. F. and Bailey, J. S.: Organic carbon, total carbon, and total nitrogen determinations in soils of variable calcium carbonate contents using a Leco CN-2000 dry combustion analyzer, Commun. Soil Sci. Plan., 32, 3243-3258, 2001.

Yang, J. E., Kim, S. C., Ok, Y. S., Lee, H. S., Kim, D. K., and Kim, K. H.: Determining minimum data set for soil quality assessment of organic farming system in Korea 19th World Congress of Soil Science, Soil Solutions for a Changing World, 1-6 August 2010, Brisbane, Australia, 2010.
Yemefack, M., Jetten, V. G., and Rossiter, D. G.: Developing a minimum data set for characterizing soil dynamics in shifting cultivation systems, Soil Till. Res., 86, 84-98, 2006.

Yu-Dong, C., Huo-Yan, W., Jian-Min, Z., Lu, X., Bai-Shu, Z., YongCun, Z., and Xiao-Qin, C.: Minimum data set for assessing soil quality in farmland of northeast China, Pedosphere, 23, 564-576, 2013.

Zdruli, P., Calabrese, J., Ladisa, G., and Otekhile, A.: Impacts of land cover change on soil quality of manmade soils cultivated with table grapes in the Apulia Region of south-eastern Italy, Catena, 121, 13-21, 2014.

Zhang, B., Zhang, Y., Chen, D., White, R., and Li, Y.: A quantitative evaluation system of soil productivity for intensive agriculture in China, Geoderma, 123, 319-331, 2004. 